UDC 332:631.1

(C) 2017

\title{
Improvement of ecological-and-economic mechanism of implementation of the market of lands of agricultural assignment in Ukraine
}

\author{
N. Palianychko, \\ candidate of economic sciences \\ Institute of agroekologii and prirodokoristuvannya of NAAN
}

The purpose. To systematize directions of development of ecological-and-economic mechanism of implementation of the market of lands of agricultural assignment. Methods. Analysis and synthesis, abstract-logical, statistical analysis, graphical. Results. Overgrowth of volumes of harvesting products of plant growing in Ukraine takes place as a result of unbalanced land-use, due to use of agro-resource potential of regions which restoring requires implementation of a complex of measures on system basis. Execution of such job is possible under condition of development of state program of use and protection of lands on the basis of transparent market turnover of land plots. Conclusions. Development of ecological-and-economic mechanism of implementation of the strategy of regulation of the market of lands in Ukraine requires development of the system of economic instruments (forcing: payments, responsibility, penalties; and encouragements: payments according to state programs, maintenance, stimulation), that will promote solution of the problem of state land policy in market conditions and first of all to provide comprehensible level of agro-ecological safety.

Key words: balanced level of land-use, agro-ecological safety, market turnover of land plots, lands of agricultural use, soil.

The uniqueness of the development of land use processes in Ukraine is determined not only by the presence of the most favorable soil and climatic conditions, but also by the deepening of the industrial, economic, social, economic and environmental crisis. The consequence of the imbalanced environmental and economic development of public relations is to exacerbate the level of environmental, economic and food security risks of the country. As a result, positive indicators of profitability in the crop sector were achieved due to the unbalanced structures of the territorial organization of the economy and fertilization, disproportions in the ratio of agricultural crop area and, in the end, a significant deterioration of the indicators of the agrarian chemical status of soils on agricultural lands. Correction of the existing state requires managerial decisions and the rational use of limited financial resources, which can be achieved by improving the environmental and economic mechanism for introducing a strategy for regulating the free circulation of land in conditions of developed market relations.

Analysis of recent research and publications. Problems in achieving a balanced level of land use have been given considerable attention in the works of D. Dobryak [1], O. Kanash [2], A. Martin [3], L. Novakovskii [4], O. Furdichko [5]. The question of improving existing instruments for charging for the use of nature, in particular for land use, is considered in the works of B. Danylyshyn, V. Mischenko [6], A. Dvigun [7], E. Krivovyaz [8].

The purpose of the research is to systematize the areas of improvement of the ecological and economic mechanism for the introduction of the market of agricultural land.

Research results. According to the State Statistics Service of Ukraine, crop production indices have a constant positive dynamics and reached $150.3 \%$ in 2015 , against the level of 2005 , which is $21 \%$ more than the level of production in 1990. These indicators differ significantly from similar indicators of livestock the industry (only $14.1 \%$ surpassed the level of 2005 and $46.3 \%$ is below the volume of production in 
1990). The largest volumes of agrarian production growth are observed in agricultural enterprises (exceeding the level of $2005-88.7 \%$, but below the 1990 level by $30.7 \%$ ) compared to households that exceeded the volumes of 2005 by only $3 \%$, and in 1990 - by $32.5 \%$. Moreover, the production of livestock sub-sectors occupies a large share in the total production of agrarian products precisely in households. The given characteristic of the indices of the produced products is explained by the level of profitability, the highest values of which in 2015 were observed for sunflower seeds - 78.4\%: the area of crops increased by more than $70 \%$ since 2005 , from 3.7 to 5.1 million hectares in 2015 , and, accordingly, the volume of collection increased from 4.7 to 11.2 million tons. The yield increased from 12.8 in 2000 to 21.6 $\mathrm{c} /$ ha in 2015 . And in the households only $17 \%$ of the total volume of this kind of products. It should be noted that the highest profitability indicators (92.9\%) were observed only for grapes [9], but given the small areas of cultivation of this culture, it does not have a significant impact on the level of agrarian ecological safety of Ukraine. Similar trends are observed for other industrial crops. The highest growth rates in 2015 compared to 2005 were achieved in the production of soybeans and canola (more than 6 times). At the same time, the reverse picture is observed in the production of feed, since the profitability of pork production in 2015 was only $12.6 \%$, milk - $12 \%$, the production of meat of cattle and poultry was unprofitable $(-16.9 \%$ and $-5.4 \%$ respectively), and only the production of eggs has reached profits at the level of almost $61 \%$.

This situation has a negative impact on the agricultural chemical indicators of the quality state of soils on agricultural lands. Against the background of a 7-fold decrease in cattle (in agricultural enterprises 17 times) during the period of Ukraine's independence, the volume of manure entering agricultural land was reduced by almost 27 times and by $28.6 \%$ - in 2015, with regard to the volume of its introduction in 2005 . The reduction in the subsistence farming sector leads to a reduction in the area under annual crops and perennial grasses of 2.3 and 1.7 times, on meadows and pastures - by 110 thousand hectares by 2015 compared with 2005. In addition, there is a complicated the situation regarding the development of the structure of land and categories of the land use in Ukraine. The dynamics of key areas for agroecological safety is shown in Figure 1.

The graphs presented illustrate the negative trends in the national practice of agricultural land use. Thus, the lack of motivation from business entities does not stimulate a thrifty attitude to the land, since, on the background of a general reduction in the area of agricultural land, the distribution of territory between its constituent components is evidence of the above statement. Reducing the areas of buffer categories of land use, which are perlites and perennial plantations, contributes to reducing the overall level of agro-ecological safety and increasing the arable land inappropriate areas. According to the State Geological Survey, currently there are 1 million 50 thousand hectares of agricultural land preserved, of which 562,7 thousand hectares are degraded, 475,6 are unproductive, 11,8 thousand hectares are technically contaminated. In addition, almost 143 thousand hectares need to be rehabilitated, 266.2 thousand hectares improved. As of 01.01.2016, land conservation was carried out only on an area of 85.3 thousand hectares $(8.1 \%$ of the territory as needed), land improvement measures were implemented on the area of 46.8 thousand hectares (17.5\%), from which only 26 thousand hectares falls on arable land. There is not only a tendency to reduce the volume of implementation of land protection measures, but also according to information [9] - to reduce the area of land by fallow (table).

Consequently, the existing way of crop management is aimed at obtaining profits, reducing the cost of production, and ultimately has a destructive effect not only on soils, but also causes a dynamic negative changes in all components of the landscape. The remote consequences of this situation with agricultural land use are difficult to assess economically. For example, according to scientists, losses associated with the use of arable land of degraded land amounted to more than 400 million USD per year in 2010, and environmental losses due to erosion, dehumidification, secondary salinisation reach the highest order [2] . Correction of the situation with the purpose of restoration and preservation of agricultural land fertility is impossible without the introduction of a complex of scientifically substantiated system of measures that requires the development and approval of a state program of land use and protection. The organizational 
and economic platform of this program provides the solution for the problem of the introduction of a transparent land market on the basis of strict compliance with the requirements of the regulatory and legislative field. The key component of this system is independent monitoring on the basis of a transparent operation of the information flow system in relation to the integrated periodic assessment and fixation of the state of agroecological characteristics of land, all legal aspects of ownership rights to land parcels and control of economic entities in relation to the methods of farming. The last one is concerned not only about the observance of scientifically grounded structure of land in the regions of any taxonomic level, but also crop rotation, expansion of areas under herbs and perennial plantations, in particular forest.

The introduction of a market of land plots on the basis of transparency and free competition requires the development of an ecological and economic mechanism, which, on the basis of improving the system of economic instruments, opens up opportunities for achieving a balanced level of land use and ensuring an acceptable level of agro-ecological safety. The principal scheme of the ecological and economic mechanism for implementing the land market regulation strategy in Ukraine (Figure 2) was worked out by the author on the basis of [4].

The key role in the system of ecological and economic mechanism belongs to the normative and legal assessment of land plots, which underlies the establishment of the market price of land. The Resolution of the Cabinet of Ministers of Ukraine N 831 dated November 16, 2016 [10] approved the prepared by the specialists of the State Geocodar of Ukraine Methodology of normative monetary valuation of agricultural land, which will come into force from March 2017. The worked out approach introduces the standard scale of capitalized rent income for the corresponding agricultural land, takes into account qualitative soil characteristics, initiates a transparent, flexible and adequate method of normative monetary valuation of land plots.

The effective functioning of this economic instrument requires the processes of regulating land use relations with the change of owner, during the giving of land, the transfer of her inheritance or on a pledge. This tool is the basis for land tax transactions, the establishment of the amount of rent and the determination of losses of agrarian production in the event of a change in the use of land for nonagricultural use.

To implement an effective transparent market for land plots, a revision of the group of economic instruments, which determines the efficiency of the impact of the ecological and economic mechanism. Improvement of the ecological and economic mechanism will take place through the development and efficient functioning of all its constituent tools, which are conditionally divided into incentive and incentive for the user of the land.

A group of incentive instruments is formed by:

- fiscal payments - land tax, rent for a land plot of different forms of ownership, payment of a single tax;

- penalties - for the unauthorized use of land plots or their misuse, pollution or disturbance of the land, removal of the fertile layer without special permits, violation of land legislation, etc.;

- economic liability for losses incurred in land plots, fees for installing land servitude.

A group of incentive tools is aimed at stimulating the introduction of a market turnover of land with maintaining an acceptable level of agroecological safety:

- Economic incentives - a complex system of tax and credit privileges or exemption from payment of land users, who, by their own efforts, implement programmatic measures for the protection of land and reproduction of their fertility on the sites ( reclamation, preservation of degraded and unproductive lands, deterioration of which was not due to the fault of the present user);

- Infrastructure costs for the development of documentation and site evaluation works; collection of state duty for the process of concluding contracts or providing paid administrative services by state bodies of land resources; 
- use of financial resources according to budget programs for the introduction of market turning of land and land protection; the use of funds from the imposition of penalties.

\section{Conclusions}

Improving the ecological and economic mechanism for implementing the land market regulation strategy in Ukraine requires the development of a system of economic instruments. Based on the improvement of the regulatory and legislative field, this will contribute to the effective resolution of tasks and measures of state land policy in market conditions and to ensure an acceptable level of agroecological safety in the conditions of achieving a balanced level of agricultural land use.

\section{References}

1. Добряк Д.С. Еколого-економічні засади рефоорування землекористування в ринкових умовах/Д.С. Добряк, Д.І. Бабміндра. - К.: Урожай, 2006. - 336 с.

2. Канаш О.П. Стратегія сучасного і подальшого використання земельних ресурсів/О.П. Канаш//Землеустрій і кадастр. - 2012. - № 2. -С. 7 - 13.

3. Мартин А.Г. Стан земельних відносин як стримуючий фрактор розвитку продуктивних сил України/А.Г. Мартин, Т.О. Євсюков//Матер. міжнар. наук. конф., м. Київ, 20 березня 2009 р./РВПС України НАН України. - К.: РВПС України НАН України, 2009. - Ч. 3. - С. $289-292$.

4. Національна доповідь щодо завершення земельної реформи; за наук. ред. Л.Я. Новаковського. - К.: Аграр. наука, 2015. - 48 с.

5. Фурдичко О.І. Екологічна безпека країни - запорука її економічної стабільності/О.І. Фурдичко//Регіональна економіка. - 2001. — № 4. - С. 18-24.

6. Данилишин Б.М. Рентна політика в Україні/Б.М. Данилишин, В.С. Міщенко. - К.: ЗАТ «Нічлава», 2004. -68 с.

7. Двігун А.О. Пріоритетні напрями регулювання рентних відносин в умовах системного реформування адміністративно-територіального устрою України/А.О. Двігун//Регіональна економіка. - 2008. - № 4. - С. $81-86$.

8. Кривов'яз Є.В. Аналіз правового забезпечення здійснення земельних рентних платежів/Є.В. Кривов'яз//Збалансоване природокористування. - 2014. - № 1. - С. 141 - 144.

9. Сільське господарство України: статист. зб. 2015. - Державна служба статистики України. К., 2016. - $360 \mathrm{c}$.

10. Постанова Кабінету Міністрів України №831 від 16.11.2016р. «Про затвердження Методики нормативної грошової оцінки земель сільськогосподарського призначення». - Режим доступу:http://zakon2.rada.gov.ua/laws/show/831-2016-п Сільське господарство України. 